Copyright (C) 2015 by Academic Publishing House Researcher

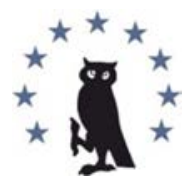

Published in the Russian Federation

European Researcher

Has been issued since 2010.

ISSN 2219-8229

E-ISSN 2224-0136

Vol. 96, Is. 7, pp. 480-489, 2015

DOI: $10.13187 /$ er.2015.96.480

www.erjournal.ru

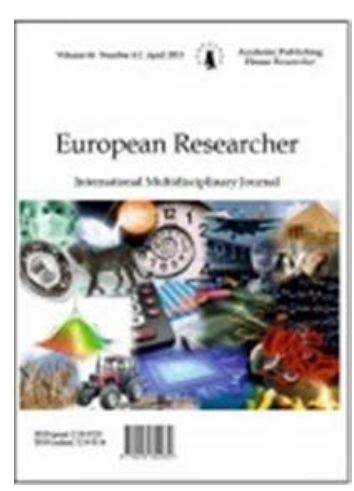

UDC 657.1

\title{
Important Aspects of Controlling
}

\author{
Galina Ju. Koblianska
}

Taras Shevchenko National University of Kyiv, Ukraine

$\mathrm{PhD}$ (Economy)

E-mail: gkoblianska@gmail.com

\begin{abstract}
The article considers controlling as a new management concept, generated by the practice of modern management in the construction industry. Organizational and methodological framework is studied in terms of assessing the success of construction projects. A set of key performance indicators (KPI) is developed based on a literature review and the practice of local companies. These figures are considered in close connection with the information environment of its existence - the administrative account and the prism of a general model of controlling. It reflects a way of introduction of indicators of achievement and success of construction projects in wages. Technical capabilities of the domestic market are analyzed to ensure the information unity of all components of the model considered controlling.
\end{abstract}

Keywords: controlling, management accounting, key performance indicators.

\section{Introduction}

Controlling is considered, on the one hand, as a philosophy, a way of thinking leaders focused on efficient use of resources and development of the company in the long term and, on the other hand, focused on the achievement of an integrated system of information-analytical and methodological support managers.

The problem is that today in the field of construction insufficient attention is paid to controlling system. The construction industry has been criticized for its lagging behind not only in Ukraine, but also abroad. In the EU, reports Latham (1994) and Egan (1998) stressed the need to improve productivity and performance measurement. Companies are faced with the dilemma of choosing between different performance measurement frameworks.

Theoretical and methodological basis of the study were the works of economists Mann, Khan, Schneider, Meyer, Weber and others. Also, reference is made to national scientists Brohun (2010), Dzioba (2013), Kozub (2009), Storozhuk (2012) and others. Unfortunately, for controlling in scientific thought there was a lack of issues to develop this issue.

Nowadays there is no single definition of "controlling", but almost no one denies that it is a new concept of management, generated by the modern management practices. Controlling (from eng. control - management, regulation, management control) is not limited by the control. However, in the construction industry it is underused. The construction industry in its 
development is dynamic by nature, the concept of success of the project remains controversial and a certain little studied specifically for the construction industry. Moreover, enterprises Industrybuilding complex has a number of specific and unique to his character. This feature makes it relevant to review the issue of key performance indicators in the model of controlling accounting and information management decision-making tool.

The object of the research is controlling in the construction industry.

The aim of the research to identify a set of common indicators for controlling, which can be used by executives and project managers to measure the performance of the construction at the project level. Achieving this goal is possible by the creation of a conceptual framework for measuring the business performance of the building organizations.

To achieve the aim the following specific tasks need to be solved:

- to analyze the state of the construction industry and its organizational structure;

- to identify ways to improve the overall efficiency and effectiveness of the construction companies;

- to identify ways to improve the work of structural divisions of the building enterprise.

\section{Methodology of the research}

Methods that are used in the work, based on the general theory of scientific knowledge. These include general scientific methods (analysis, synthesis, deduction), empirical theoretical (formalization, hypothetical) empirical and methodological (cash-analytical, synthesis) methods of research. During the research of important aspects of controlling using the following methods: systems analysis (for opening the category "controlling"); methods of induction, deduction, abstraction and formal logic; comparison, grouping.

\section{Results}

Up to this date, the industrialized countries of the West took two basic concepts of controlling due to their functional purpose and institutional design:

- Controlling-based accounting system;

- Controlling with a focus on information.

The concept of controlling oriented accounting system related to the implementation of the goals of information through the use of accounting data. The focus is on cost parameters. It is mainly aimed on ensuring profit. The concept of controlling focused on accounting data, is mainly responsible for operational needs of the company and partially meets the strategic goals of its development.

The concept of controlling oriented information includes not only the use of accounting data (quantitative information) but also qualitative information directly related to the economic activities of enterprises. According to this concept main task consist of controlling information support management decisions by management. It should support intra-process management through targeted recruitment and information processing. This concept involves the incorporation of controlling with a wide range of information problems in the structure of enterprise management. However, the solution to this problem, in practice, is quite complicated. This is a core driving force behind the new views on management, is both internal and external optimization of the company. Of course, this led to a rethinking of the performance management system based on a balanced performance measurement.

The difference between performance management and measurement of effectiveness can be explained as follows: the first concept "... is considered as a closed control system, which deploys the policy and strategy, as well as the ability get feedback from different levels in order to control the efficiency of the system," while measuring system efficiency "... an information system underlying the performance management process and is critical to the effective and efficient functioning performance management system." Thus, measuring the effectiveness of a process "... to determine whether the organization is successful or more persons are successful in achieving the objectives" (Evangelidis, 1992). To achieve this, background information on the company strategy and operational processes is measured in a quantitative form in order to track the "vital signs" of the company.

Regardless of their size of any business can be described as a system of financial relationships and cash flow, driven by a management decision. Such a system is called controlling, we borrowed 
it from nature: it is maintaining the necessary balance (for example, temperature, humidity, energy supply - in nature or profit, revenue performance - in the economy). Equilibrium is achieved by the fact that after a certain period of time is compared with the predetermined value and the actual state is determined not require intervention (counteracting measures) to achieve the required or desired state, and it is carried out if necessary (Mann, Meier, 1995).

Set state of the economy determines the enterprise planning, while the actual situation is monitored in management accounting. Therefore, a comparison of planned and actual performance is the core of controlling system. Plan - is an expression of the desired state that we want, the actual state of affairs - a numeric result of our activities that we can analysis of actual and planned targets, comparison of the desired and actual provide an incentive to make better use of their opportunities and in their desires yet remain on the ground.

The complexity of the development and implementation of controlling model based on KPI, for the construction industry management positions and for the service units is a challenge. First of all, due to the fact that results are often difficult to describe quantitatively. Traditionally, the list of key performance indicators of staff was determined on the basis of the mission and vision of the company, its strategic objectives card (balanced scorecard - on BSC). Implementation of KPI system from scratch in the enterprise usually done in several steps.

Step 1. Determine the mission and strategy. In order to achieve results in the long term, the company needs to shape clear mission and a strategy that will achieve the goals and desired outcomes. The company's strategy is to be divided into specific strategic directions in which you can select individual tasks for each structural unit. And it is necessary to ensure the success of this phase is to determine the priorities of the strategic directions and coordination between departments.

Step 2: Definition and cascading critical success factors. In the second stage, the most important factors of efficiency and effectiveness, that is, those aspects of the company, which are vital to meet the goals which were set. Then these parameters are distributed by cascading (decomposition) at lower levels of the company. Consider the process of decomposition of the strategic indicators on the example of investment and construction company (pic. 1).

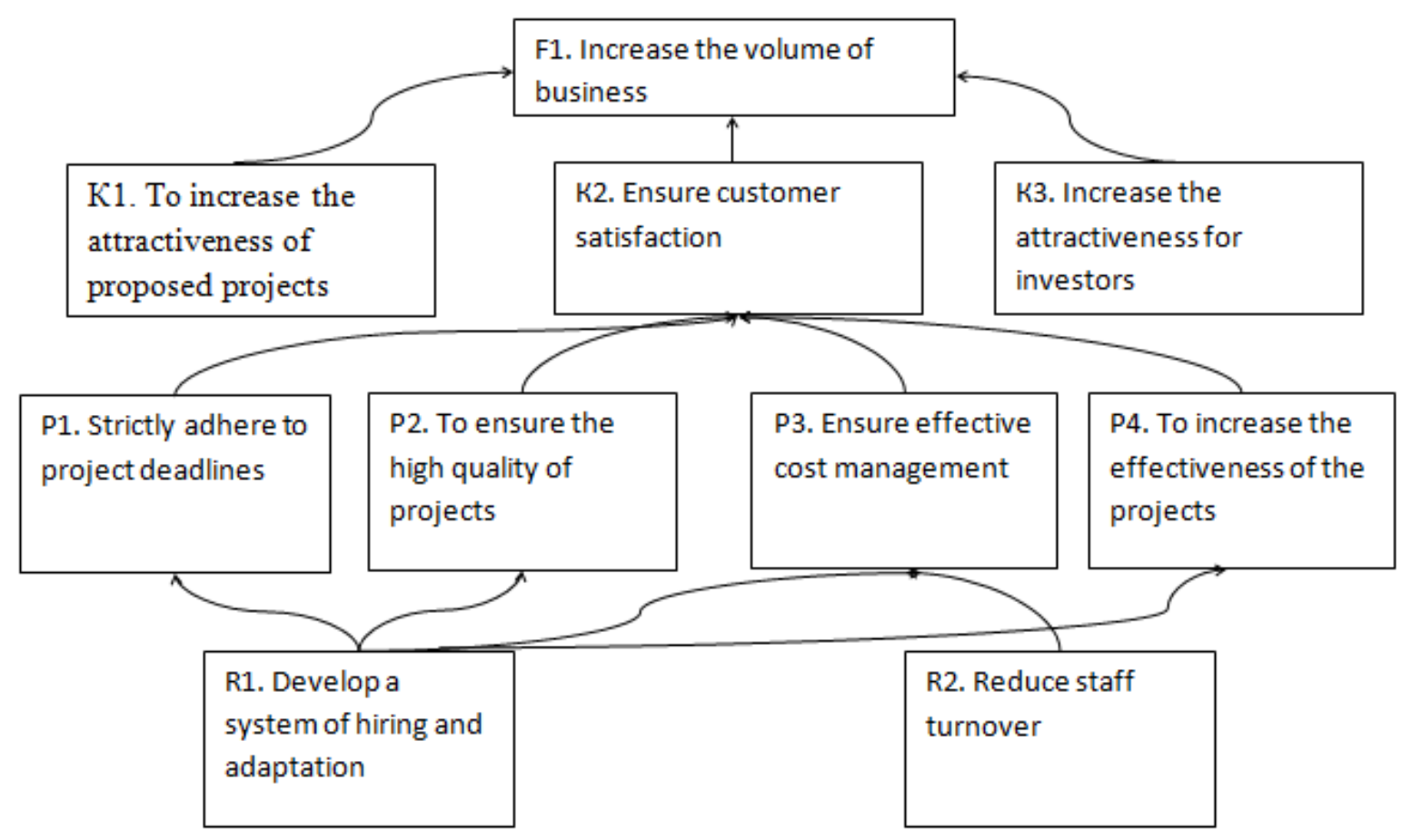

Pic. 1. Strategy Map investment and construction company (Gershun, 2005) 
The Balanced Scorecard allows to brake down global strategy from the top level to the lower, from the holding to the subsidiaries as part of the company for each unit within the division to each employee. Each employee becomes responsible for the achievement of an indicator. This technique makes a person think about their long-term goals, the extent of their compliance with the objectives of the company and the possibility of combining them.

Consider the example of decomposition parameters between units (Table. 1).

- Purpose: P1. Strictly adhere to the timing of projects

- Indicator: P111. Project implementation period

- Method of payment: The ratio of the number of projects delivered on time to the total number of projects

Table 1. Sample decomposition parameters between units (Gershun, 2005)

\begin{tabular}{|l|l|l|l|l|l|l|}
\hline $\begin{array}{l}\text { Building } \\
\text { area } \\
\text { (Bild) }\end{array}$ & $\begin{array}{l}\text { Preparation } \\
\text { for } \\
\text { construction } \\
\text { (PC) }\end{array}$ & $\begin{array}{l}\text { General } \\
\text { contract } \\
\text { (GC) }\end{array}$ & $\begin{array}{l}\text { The produc- } \\
\text { tion base } \\
\text { (PB) }\end{array}$ & $\begin{array}{l}\text { General } \\
\text { designer } \\
\text { (GD) }\end{array}$ & $\begin{array}{l}\text { Architec } \\
\text { ture (A) }\end{array}$ & $\begin{array}{l}\text { Exploit } \\
\text { ation } \\
\text { (Ex) }\end{array}$ \\
\hline $\begin{array}{l}\text { П11- Bild } \\
\text { The term } \\
\text { projects }\end{array}$ & $\begin{array}{l}\text { П111- PC. } \\
\text { Term } \\
\text { transferring } \\
\text { the necessary } \\
\text { documentation }\end{array}$ & $\begin{array}{l}\text { П111- GC } \\
\text { construction } \\
\text { period }\end{array}$ & $\begin{array}{l}\text { П111-(PB) } \\
\text { term } \\
\text { production }\end{array}$ & $\begin{array}{l}\text { П111-(GD). } \\
\text { The term in } \\
\text { the } \\
\text { contract }\end{array}$ & $\begin{array}{l}\text { П111-A. } \\
\text { The term } \\
\text { in the } \\
\text { contract }\end{array}$ & $\begin{array}{l}\text { П11-Ex. } \\
\text { Terms } \\
\text { impleme } \\
\text { nt } \\
\text { projects }\end{array}$ \\
\hline
\end{tabular}

Step 3: Defining KPI. Stage is characterized by the selection process of concrete measures to implement the strategy. Tools to determine the factors of efficiency and effectiveness are a KPI: quantitative indicators expressed in digital form. With their wide variety of determining a focus only on the most significant of them, that is the key. It is necessary in terms of the reality of their implementation, the quality of monitoring, encouraging employees to exercise appropriate action.

To determine the usefulness and applicability in practice performance data, SMART model is usually applied:

Specific (Specific) - KPI must be one widespread definition, eliminates the risk of free interpretation, thus providing the only reliable standard applications.

Measurable (Measurable) - KPI is an active means of measurement that specifies the standard rate or the budget.

Achievable (Available) - KPI quite clear and is described in detail in order that it can be applied in practice.

Relevant (Relevant) - KPI must be measured real and important aspects of the strategy of organization, directly contributing to the implementation, otherwise, the KPI is simply useless "obstruction".

Time-Phased (timing) - KPI, ideally, should express the relationship between the chosen performance indicator and the time period during which it is considered to set a time KPI comparison criterion in the future.

For each of the key indicators methodology has been developed to allow a calculation of highquality employee performance.

For example, staff service units following key performance indicators:

- Implementation of the plan of work for the month

- Compliance with document

- Ease of communication and focus on service production units and others.

Each indicator has a weight in the total amount of the premium wage as $100 \%$.

For the employees of construction and installation department key performance indicators in their indissoluble connection with the information necessary for calculating and specifying the documentation where it can be found, it is shown in Table 2. 
Table 2. Balanced Scorecard Construction and assembly department

\begin{tabular}{|c|c|c|c|}
\hline \multirow[t]{2}{*}{ Goal line } & \multicolumn{3}{|c|}{ Indicator of achievement goals } \\
\hline & KPI [10] & $\begin{array}{l}\text { The necessary information } \\
\text { to calculate }\end{array}$ & Examples of documents used \\
\hline $\begin{array}{l}\text { Operational } \\
\text { effectiveness } \\
\text { maximization }\end{array}$ & $\begin{array}{l}\text { The percentage of } \\
\text { construction and } \\
\text { demolition waste } \\
\text { that recycled }\end{array}$ & $\begin{array}{l}\text { - Waste by type and } \\
\text { construction projects; } \\
\text { - Waste subject to reuse; }\end{array}$ & $\begin{array}{l}\text { №M-29 "Report on the } \\
\text { actual use of materials in } \\
\text { construction in comparison } \\
\text { with industrial standards" } \\
\text { Welfare report form №M-19 } \\
\text { Instructions for terms and } \\
\text { conditions of the collection, } \\
\text { temporary placement of } \\
\text { industrial and household } \\
\text { waste in the enterprise }\end{array}$ \\
\hline $\begin{array}{l}\text { Operational } \\
\text { effectiveness } \\
\text { maximization }\end{array}$ & $\begin{array}{l}\text { Net revenue per } \\
\text { employee Project }\end{array}$ & $\begin{array}{l}\text { Net income for the project } \\
\text { in terms of construction } \\
\text { stages; The number of } \\
\text { workers at each stage }\end{array}$ & $\begin{array}{l}\text { egister of work performed } \\
\text { (form number CB-6) Sample } \\
\text { form number } 1 \text { "Report on } \\
\text { the implementation of the }\end{array}$ \\
\hline $\begin{array}{l}\text { Operational } \\
\text { effectiveness } \\
\text { minimization }\end{array}$ & $\begin{array}{l}\text { Cost per square } \\
\text { meter }\end{array}$ & $\begin{array}{l}\text { the cost of the project and } \\
\text { the total area. Price per } \\
\text { square meter is calculated } \\
\text { only for new construction } \\
\text { and refurbishment } \\
\text { projects. }\end{array}$ & $\begin{array}{l}\text { contract on the construction } \\
\text { site for the period (month / } \\
\text { year)"; Sample form number } \\
2 \text { "Summary Report on the } \\
\text { cost of work performed under } \\
\text { the contract on the } \\
\text { construction site"; Sample }\end{array}$ \\
\hline $\begin{array}{l}\text { Operational } \\
\text { effectiveness } \\
\text { minimization }\end{array}$ & $\begin{array}{l}\text { Actual vs. target } \\
\text { time for } \\
\text { construction work }\end{array}$ & $\begin{array}{l}\text { Actual hours on the } \\
\text { project, written and } \\
\text { reviewed against the } \\
\text { original plan (basic) man- } \\
\text { hours on a monthly basis. }\end{array}$ & $\begin{array}{l}\text { form number } 3 \text { "delivery- } \\
\text { acceptance act of } \\
\text { construction works." }\end{array}$ \\
\hline $\begin{array}{l}\text { Operational } \\
\text { effectiveness } \\
\text { minimization }\end{array}$ & $\begin{array}{l}\text { The actual duration } \\
\text { of the project* }\end{array}$ & $\begin{array}{l}\text { Date of commencement of } \\
\text { preparatory work, } \\
\text { construction date, date } \\
\text { last act of the works. }\end{array}$ & $\begin{array}{l}\text { Agreement, contract, deed of } \\
\text { transfer, acts of acceptance } \\
\text { and help FNo CB-3 }\end{array}$ \\
\hline
\end{tabular}

* for example decomposition rate was made between units

Calculation of labor costs and material incentives for staff should possess a high degree of adaptability, flexibility. List of KPI for each employee, as well as its weight, be subjected to adjustment depending on the goals and tasks of the employees. For example, for the implementation of the approved schedule document, you can improve the relevance of the KPI. And as soon as compliance with these requirements will naturally reduce the importance of this factor.

To cascade to the required level management balanced scorecard, go to binding wage for our example the head of the construction project with its objectives (see Table 3). 
Table 3. How the employee's salary with his goals

\begin{tabular}{|c|c|c|}
\hline notion & determination & result \\
\hline 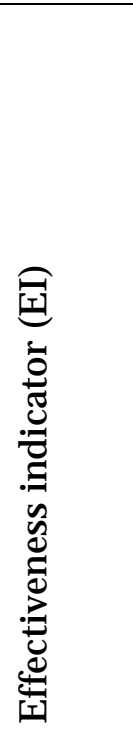 & $\begin{array}{l}\text { - or the ratio of the actual value of the indicator to its } \\
\text { planned value (for parameters whose values we seek to } \\
\text { maximize). } \\
\text { Example: Net revenue per employee project. If the value of } \\
\text { the planned income last month was equal to } 100 \text { USD, and } \\
\text { in fact received } 75 \text { USD, will dorivnyuty performance index } \\
\text { of } 0.75 \text { (or } 75 \% \text { ). } \\
\text { - attitudes or values of the planned its actual value (for } \\
\text { indicators whose values we seek to minimize). } \\
\text { Example: Percentage marriage. If the percentage of } \\
\text { marriage last month, we planned to keep at } 12 \% \text {, but in fact } \\
\text { worked for only } 8 \% \text { of Marriage, performance index is } 1.5 \\
\text { (or } 150 \% \text { ). }\end{array}$ & $\begin{array}{l}\text { allows you to schedule } \\
\text { activities to achieve the } \\
\text { goals, fill incentive } \\
\text { system fact sheet. }\end{array}$ \\
\hline 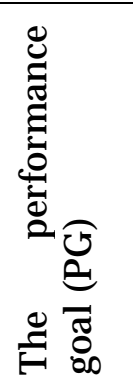 & $\begin{array}{l}\text { - product performance or other indices related to this goal } \\
\text { (indicators are equal significance to us): } \\
\text { PG =Pn1* ... }{ }^{*} \text { Pnn } \\
\text { - or the amount of performance indicators relating to the } \\
\text { purpose of considering the significance of each indicator } \\
\text { (indicators have different significance to us): } \\
\text { PG = Ci1 Pn1 }+^{*}+{ }^{*} \text { Cin Pnn }\end{array}$ & $\begin{array}{l}\text { directs the employee to } \\
\text { focus on achieving goals, } \\
\text { demonstrates a clear link } \\
\text { with the objectives and } \\
\text { general productivity of } \\
\text { wages. }\end{array}$ \\
\hline 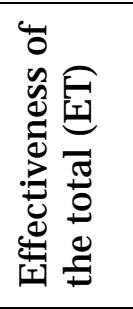 & $\begin{array}{l}\text { - product performance or other purposes for which the } \\
\text { employee (s having equal importance to us): } \\
\text { ET }=\text { Pp } 1 * \text { * Ppn } \\
\text { - or the sum of all performance objectives for which the } \\
\text { employee, given the importance of each goal (objectives } \\
\text { have a different significance to us): } \\
\text { ET =Ci1Pp } 1^{*}++{ }^{*} \text { Cin Ppn }\end{array}$ & $\begin{array}{l}\text { simplifies the calculation } \\
\text { of employee benefits, } \\
\text { demonstrates its overall } \\
\text { effectiveness in meeting } \\
\text { the strategic objectives } \\
\text { and their relationship to } \\
\text { his wages. }\end{array}$ \\
\hline
\end{tabular}

Compiled by the author based (Dembskaia, 2010)

Using expert advice for payroll employees will use the formula:

Salary $=$ base rate $+\mathrm{ET}^{*}$ Base rate

At this rate base Size recommended Size in set "The average cost specialist in the market" / 1.7. This means, someone from personnel Receive average wage charge Only when the his GENERAL PERFORMANCE 0.7.

Such determined system of indicators are created to show what we actually walk in and get at the start. Maintenance and motivation system is calculated upon based indicators.

Stage 4 Development and evaluation of BSC. For the adoption of management decisions should be designed on financial and non-financial indicators, which will provide necessity and usefulness of information in models controlling.

For joined KPI indicators in balanced way there is a need to follow several conditions. First, we need to understand what specifically are the object of control - specific manufacture process or unit. Secondly, we need to provide exact evaluations of key indicator solutions for strategic problem, which will seize the list of KPI and leave only most significant of them. 
Stage 5. Choice of technical security. Not one of the most important stages. Definition for the source data is information filled with indicators. Information used should fulfill the terms of fulfillers, legitimacy, be presented in time be objective.

Consider How KPI system connected with management controlling and accounting. Patriotic exist in practice several options - fully/ partially/ non related.

If KPI and related budgeting poorly or not related at all - is technically inconvenient - there is a need to implement and support RED Clearing system: one plans KPI, and another - budgets. But this can be a rather small problem in comparison with much wider one - methodological, when systems contradict each other. For example, a company can have KPI and motivation; gain and develop client-oriented quality, and at this same motivation to cut budget expenses. This is an everyday dilemma for managers.

KPI system and budgeting should be closely related, in Ideal, This is a one system at least at methodological level. Information and commercial-architecture in this way can look as following (Starinskij, 2015):

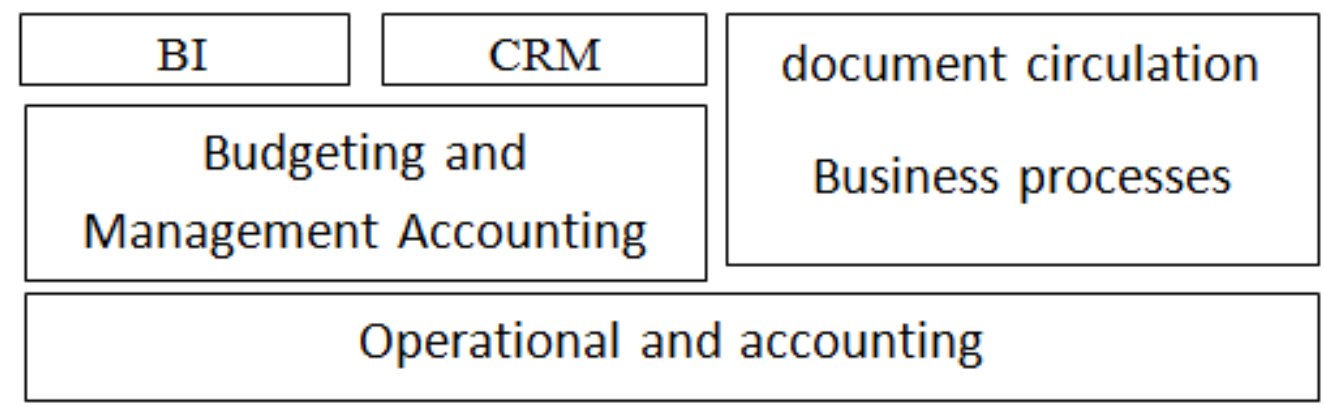

Pic. 2. Information and technical architecture controlling.

Even if every block of the scheme - a separate database with their software, still they are well integrated, as long as data is entered once and at an acceptable speed for business exchange.

Software solution for controlling model building organizations should include the following modules are actually planning module (budgeting);

- Due to the accounting module (management) accounting;

- module connection with the development of design estimates.

Currently, typical complex solutions containing all three modules do not exist. There are separate software products that provide some of the functionality of two of the three modules. It may be, for example, budgeting and accounting, have no connection with the estimates, or estimates program and a program for accounting (for example, the possibility of discharge from the program budget in WinAVeRS <1C: Accounting> Information for operations write-off materials) Non thus with budgeting.

Selecting an automated budgeting system in the enterprise is very important and quite complex. As a rule, he is referring to an assessment of commercially available software for managing and controlling the following criteria: cost of the system, the ability to create, analyze and control the budgets of companies, import / export data to accounting (accounting) system, a skilled developer support, the presence of a number of successful implementations in Ukraine.

\section{Conclusions}

Thus, the system of key performance indicators - is an effective tool of information support of management decision making. The management company should try to implement the system in close connection with controlling system, ensure efficiency and effectiveness, as well as timely notification of a fault, the most important economic-financial and operational aspects of the business.

In our opinion, the poor state of the construction industry in its organizational and methodological approaches to management decisions can be resolved is through a system of KPI. Important point here is implementation of the resources and economically viable by improving the overall efficiency and effectiveness of the company's accounting specifics of a particular industry, employee motivation through the connection between their specific duties and mission, strategy and goals of the company. Management unit of the enterprise, having a mechanism for identifying 
and measuring the powerful / weak points through a system of indicators, is able to determine the performance of each division and influence the process of a long-term balanced functioning of the company.

\section{References:}

1. Egan, J. (1998) Rethinking Construction: Report of the Construction Task Force, London: HMSO. - http:// www.constructingexcellence.org.uk [08.09.2014].

2. Брохун Н. С. (2010). Бухгалтерський облік як інструмент інформаційного забезпечення системи контролінгу : автореф. дис. канд. екон. наук. - Житомир.

3. Дзьоба В.Б. (2013). Теоретико-методологічна база побудови і використання системи контролінгу // Вісник Національного університету "Львівська політехніка". Менеджмент та підприємництво в Україні: етапи становлення і проблеми розвитку, № 767.

4. Козуб О.В. (2009). Формування системи управління промисловими підприємствами на засадах контролінгу : автореф. дис. канд. екон. наук. - Запоріжжя.

5. Сторожук Н.В. (2012). Інвестиційний контролінг як засіб діагностики стану економічної безпеки будівельного підприємства // Формування ринкових відносин в Україні, № 10.

6. Evangelidis, K. [1992]. "Performance measured performance gained"// The Treasurer.

7. Манн Р., Майер Э. (1995). Контроллинг для начинающих. - Москва: Финансы и статистика.

8. Гершун А. М. (2005). Разработка сбалансированной системы показателей. Практическое руководство с примерами. - Москва: ЗАО «Олимп-Бизнес».

9. Дембская О.О. (2010). Построение системы управления мотивацией персонала на основе ключевых показателей эффективности (КРI) // Вестник НТУ "ХПИ", № 64.

10. Старинский Б. Как разработать показатели KPI. http://www.intalev.ua / library/articles [10.07.2015].

11. Becker, T.C., J aselskis, E.J., El-Gafy, M., Du, J . (2012). Industry practices for estimating, controlling and managing key indirect construction costs at the project level // Construction Research Congress 2012: Construction Challenges in a Flat World, Proceedings of the 2012 Construction Research Congress.

12. Bredehoeft Jr., P.R. (2005). Controlling non-construction costs // AACE International Transactions.

13. Hu, C., Liang, S., Wang, J., Jiang, H. (2006). A new process controlling model of construction project and its application // J ianzhu J iegou Xuebao/J ournal of Building Structures, Nr. 27 (SUPPL.).

14. Бібліотека ключових показників ефективності. - http://kpilibrary.com.

15. Latham, M. (1994), Constructing the Team, London: HMSO. -http://www. constructingexcellence.org.uk [08.09.2014].

16. Nguyen, L.D., Phan, D.H., Tang, L.C.M. (2013). Simulating construction duration for multistory buildings with controlling activities // Journal of Construction Engineering and Management, Vol. 139, Nr. 8.

17. Opfer, N., Shields, D.R. (2014). Controlling workers compensation costs in construction // ASEE Annual Conference and Exposition, Conference Proceedings.

18. Ranasinghe, U., Ruwanpura, J. (2012). Continuous process planning and controlling techniques for construction productivity performance enhancement // Construction Research Congress 2012: Construction Challenges in a Flat World, Proceedings of the 2012 Construction Research Congress.

19. Shenjun, Q., Lanlan, Z., Shengping, Z., Hanbin, L., Huahu, K. (2009). Study on integrated and controlling management information system of construction enterprise groups // Proceedings - 2009 International Forum on Information Technology and Applications, IFITA 2009.

20. Shuai, Q., He, Y. (2011). Study on time controlling for large-scale construction project // International Conference on Management and Service Science, MASS 2011.

21. Tsygalov, Yu.M. (2003). Methodological foundations of construction of system for controlling the metallurgical holding // Izvestiya Vysshikh Uchebnykh Zavedenij. Chernaya Metallurgiya. 
22. Wang, R.L., Li, S.R., Deng, X.L. (2013). Study about controlling of procurement cost of construction material // Applied Mechanics and Materials.

\section{References:}

1. Egan, J. (1998) Rethinking Construction: Report of the Construction Task Force, London: HMSO. - http:// www.constructingexcellence.org.uk [08.09.2014].

2. Brokhun N.S. (2010). Bukhgalters'kii oblik yak instrument informatsiinogo zabezpechennya sistemi kontrolingu : avto $\neg$ ref. dis. kand. ekon. nauk. - Zhitomir.

3. Dz'oba V.B. (2013). Teoretiko-metodologichna baza pobudovi i vikoristannya sistemi kontrolingu // Visnik Natsional'nogo universitetu "L'vivs'ka politekhnika". Menedzhment ta pidpriєmnitstvo v Ukraïni: etapi stanovlennya i problemi rozvitku, № 767.

4. Kozub O.V. (2009). Formuvannya sistemi upravlinnya promislovimi pidpriemstvami na zasadakh kontrolingu : avto־ref. dis. kand. ekon. nauk . - Zaporizhzhya.

5. Storozhuk N. V. (2012). Investitsiinii kontroling yak zasib diagnostiki stanu ekonomichnoï bezpeki budivel'nogo pidpriemstva // Formuvannya rinkovikh vidnosin v Ukraïni, № 10 .

6. Evangelidis, K. [1992]. "Performance measured performance gained"// The Treasurer.

7. Mann R., Maier E. (1995). Kontrolling dlya nachinayushchikh. - Moskva: Finansy i statistika.

8. Gershun A.M. (2005). Razrabotka sbalansirovannoi sistemy pokazatelei. Prakticheskoe rukovodstvo s primerami. - Moskva: ZAO «Olimp-Biznes».

9. Dembskaya O.O. (2010). Postroenie sistemy upravleniya motivatsiei personala na osnove klyuchevykh pokazatelei effektivnosti (KPI) // Vestnik NTU "KhPI", № 64.

10. Starinskii B. Kak razrabotat' pokazateli KPI. - http://www.intalev.ua / library/articles [10.07.2015].

11. Becker, T.C., J aselskis, E.J ., El-Gafy, M., Du, J . (2012). Industry practices for estimating, controlling and managing key indirect construction costs at the project level // Construction Research Congress 2012: Construction Challenges in a Flat World, Proceedings of the 2012 Construction Research Congress.

12. Bredehoeft J r., P.R. (2005). Controlling non-construction costs // AACE International Transactions.

13. Hu, C., Liang, S., Wang, J., Jiang, H. (2006). A new process controlling model of construction project and its application // Jianzhu J iegou Xuebao/J ournal of Building Structures, Nr. 27 (SUPPL.).

14. Biblioteka klyuchovikh pokaznikiv efektivnosti. - http:// kpilibrary.com.

15. Latham, M. (1994), Constructing the Team, London: HMSO. -http://www. constructingexcellence.org.uk [08.09.2014].

16. Nguyen, L.D., Phan, D.H., Tang, L.C.M. (2013). Simulating construction duration for multistory buildings with controlling activities // Journal of Construction Engineering and Management, Vol. 139, Nr. 8.

17. Opfer, N., Shields, D.R. (2014). Controlling workers compensation costs in construction // ASEE Annual Conference and Exposition, Conference Proceedings.

18. Ranasinghe, U., Ruwanpura, J . (2012). Continuous process planning and controlling techniques for construction productivity performance enhancement // Construction Research Congress 2012: Construction Challenges in a Flat World, Proceedings of the 2012 Construction Research Congress.

19. Shenjun, Q., Lanlan, Z., Shengping, Z., Hanbin, L., Huahu, K. (2009). Study on integrated and controlling management information system of construction enterprise groups // Proceedings - 2009 International Forum on Information Technology and Applications, IFITA 2009.

20. Shuai, Q., He, Y. (2011). Study on time controlling for large-scale construction project // International Conference on Management and Service Science, MASS 2011.

21. Tsygalov, Yu.M. (2003). Methodological foundations of construction of system for controlling the metallurgical holding // Izvestiya Vysshikh Uchebnykh Zavedenij. Chernaya Metallurgiya. 
22. Wang, R.L., Li, S.R., Deng, X.L. (2013). Study about controlling of procurement cost of construction material // Applied Mechanics and Materials.

УДК 657.1

\section{Актуальные аспекты развития контроллинга}

Галина Юрьевна Коблянская

Киевский национальный университет имени Тараса Шевченка, Украина

Кандидат экономических наук

E-mail: gkoblianska@gmail.com

Аннотация. Рассматривается контроллинг как новая концепция управления, порожденная практикой современного менеджмента в строительстве. Исследованы организационно-методологические основы для оценки успешности проектов строительства. Набор ключевых показателей эффективности разрабатывается на основе обзора литературы и практики отечественных компаний. Такие показатели рассмотрены в неразрывной связи с информационной средой своего существования - управленческим учетом и через призму общей модели контроллинга. Отражены пути внедрения показателей достижения результатов и успешности строительных проектов в систему оплаты труда. Проанализированы технические возможности отечественного рынка по обеспечению информационной единства всех рассмотренных составляющих модели контроллинга.

Ключевые слова: контроллинг, управленческий учет, ключевые показатели эффективности. 